\title{
A Brasília, as Brasílias: Localizando a narrativa "comum" nos usos da cidade.
}

\author{
Frederico Vianna Torres Diniz \\ Orientador: Edson de Silva Farias \\ Dissertação de Mestrado \\ Data da defesa: 28.02.2013
}

$\mathrm{N}$

ascida de um esforço conjunto, a pesquisa analisa o espaço metropolitano de Brasília à luz de uma unicidade simbólico-narrativa-modernista ali materializada. Ao analisarmos o processo do redesenho da cidade-estado para a metrópole, destacamos a lógica sócio-espacial na qual se evidencia o Plano Piloto como "marco cognitivo" dentro do conjunto heterogêneo que conforma o Distrito Federal. A pesquisa analisa a malha metropolitana da capital à luz de uma tensão estrutural, a saber, de ser o espaço urbano da metrópole atravessado pela prevalência de uma narrativa formada predominantemente em torno de rotinas e protocolos condensados na região planejada. Mais especificamente, considerando o Plano Piloto no centro do ordenamento espacial brasiliense, e ainda em se tratando da incontornável característica de irrupção histórica da capital, partimos da constatação de se tratar tal área enquanto "lugar" reservatório modernista, marcado pelo acúmulo de saberes. Nesse sentido, sugerimos que o Plano Piloto condensa e fornece parâmetros de normalidade pelos quais se dá a hegemonia narrativa constatada no contexto metropolitano do Distrito Federal. Isso corresponde ao que denotamos por narrativa comum da cidade: tal síntese expressa-se em categorias de entendimento naturalizadas. Lançamos mão da noção de narrativas para propor como o planejamento modernista torna-se compreensível à luz da missão histórica que o originou. Trouxemos também a concepção de espaço enquanto a priori social, com isso sugerimos que a noção extrapola a componente meramente física e econômica: compreendemos o espaço enquanto categoria de entendimento, a qual fornece parte dos elementos de apreensão, significação, reconhecimento e criação do mundo social. Em se tratando de pensar o espaço urbano de Brasília enquanto a priori social, buscamos fundamentalmente qualificar como se forma uma síntese de saberes e afetividades incorporadas por meio da qual a realidade sócio-urbana torna-se "familiar" e "natural".

Palavras-chave: Espaço urbano, Narrativas, Usos, Metrópole, Relatos cotidianos. 